\title{
Searching for the Source: Neil Gunn's Highland River
}

\author{
David Clark \\ University of La Coruña
}

\begin{abstract}
Neil Gunn's Highland River is arguably the most European of the Scottish novels to come out of the period often misleadingly referred to as the Scottish Literary Renaissance of the 1920s and 30s. This article argues that the novel is an important work, largely-ignored outside Scotland which successfully unites the Scottish metaphysical tradition with many of the formal and thematic devices of twentieth-century European modernism.
\end{abstract}

Highland River (1937) was the seventh novel published by the Scottish novelist Neil M. Gunn, and the last he would write before leaving his job as a government excise official in a Highland whisky distillery to become a full-time writer. Highland River reveals Gunn as a mature, confident writer, who, after the historical realism of his previous novel, Butcher's Broom (1934), ventured into the territory of modernist literary techniques in what can arguably be considered, alongside Hugh MacDiarmid's book-length 1924 poem $A$ Drunk Man Looks at the Thistle, as one of the greatest achievements of the literary phenomenon which came to be known as the Scottish Renaissance.

Although the novel shares a similar subject matter to that of Gunn's first novel Morning Tide (1931), that is, the developing consciousness of a young boy within a small Highland community, both structurally and philosophically it is a much more profound work of art than the earlier novel. It represents Gunn's most important venture into the stylistic and thematic canons of literary modernism, and it is not, therefore, surprising that the idea for the novel was suggested to Gunn by T.S. Eliot and Frank Morley who had visited Gunn, representing the publishers Faber, at the writer's Inverness home. Gunn's biographers Hart and Pick report Gunn as saying that Eliot had told him "about a Yorkshire novelist who had just done a novel on his river at home, and suggested I do a book on my own river" (p. 138). 
The result was Highland River, a novel which revealed a level of stylistic skill and narrative sophistication which, it could be argued, remains one of the unacknowledged masterpieces of English-language fiction of the 1930s.

McCulloch considers that the novel's narrative pattern "with its Proustian time-shifts, is more sophisticated than that of Gunn's work as a whole" (p. 76), and both Price and Gifford acknowledge the influence of Eliot, Proust and Virginia Woolf in Highland River (pp. 65, 112). The intricate structure of the novel reflects the complexity of the vision which Gunn approaches in the novel through the shifting perspectives of a single centre of consciousness, Kenn, at different stages in his life and thus at different levels of maturity. Highland River traces the maturing process of the boy, Kenn, but also uses a complex system of analepsis which takes the reader from the young Kenn to the adult Kenn and back again throughout the novel. The typically modernist quest for self-discovery is duplicated in that, as the consciousness of the child develops, the exploration of his own past leads to further self-discovery.

The river of the title is both the symbol of and the setting for such discovery. The journey to the source of the river parallels the journey to the source of the self, and the life cycle of the salmon, in Celtic folklore the source of wisdom, is used metaphorically to illustrate the life of Kenn as he moves from boyhood to manhood. Beginning at the mouth and ending at the source of the river, the development of the novel coincides with the various stages of the river and their geographical, historical and spiritual environment. As Pick notes, the act of tracing the source of the stream is equivalent to tracing the stream of life itself, and the source of individual and communal identity (p. 23). The novel moves through a series of childhood "moments of delight", which are then followed in an apparently random manner by experiences in the life of the adult Kenn - seen variously as student, soldier and scientist - which are in some way related to them. Thus, although the boy generates the nucleus of an experience which the adult tries to discover, the adult's "present" is coexistent with the child's "past", creating what Roderick Watson calls "a series of overlapping presents"(p. 399). If, as Eliot states in "Burnt Norton", "all time is eternally present", the tracing of Kenn's river is a means of tracing both past and future in a perennial present.

The community in which Kenn lives is similar in many ways to that of Morning Tide. Gunn himself, in the epistolary dedication to his brother John claims that "some of the characters seem to have strayed in from Morning Tide." The economic structure is similar to that of Hugh's community in the earlier novel, based on sea-fishing and crofting, and although some years were more rewarding than others, the economic results "were never greatly dissimilar over a whole year or over ten years." This meant that there existed "a communal feeling so genuine that the folk themselves never thought about it"(Gunn, 1937: 17). The family is also similar to that of Morning Tide, although the conflicting sisters are not present in Highland River. The family is at the centre of the community, the mother at the centre of the family. Family affection and the unity of the community, based on shared traditions give rise to a social structure which is vital and emotionally and economically selfsufficient, from the summer herring-season to the winter grazing of the animals in the 
shieling, with none of the alienating qualities of industrial labour which, according to the narrator, takes away man's dignity and decision, that "drains him of some element of native splendour that is as real as his memory of the colour in the seaman's cheeks" (Gunn, 1937: 45). The distrust of comfortable living and the belief in the inherent goodness of constant struggle create in the member of such an archetypal community "a far-sighted steadiness" and so, in "this half-light of the world the man seems to become abstracted from all men and takes upon himself the burden of decision" (ibid.: 47).

Kenn is first presented as he awakens from sleep. This awakening is important in that it is a coming to of consciousness, thus heralding from the start of the work the central theme of spiritual awakening. At the beginning of the novel, at the river mouth, the young Kenn has his first significant contact with the river. In the Well-pool he sees a large salmon, and single-handedly manages to capture the fish. The sight of the salmon provokes an ancestral memory in Kenn. After "a saga of a fight", the young boy lands the fish. The salmon, an omnipresent image in Gunn's work, is important in Celtic myth as the source of wisdom, and it becomes a powerful symbol throughout the novel. The boy's quest towards the source is echoed by the salmon's instinctive return to its breeding grounds, a journey which takes it from the darkness of the depths of the Atlantic continental shelf to the brightness of the shallows of the river as it approaches its source.

The salmon is seen as an "individualist", living a solitary life, but it moves towards its own kind at the end of its journey. The elder Kenn wonders what the salmon feels at the moment of awakening, and attempts to reach a logical explanation. The salmon, he believes may be "disturbed by awakened memories of the tumbling waters of his youth", by what he describes as "an exquisite nostalgia" (p. 28) for an ever present past. The scientist in him rejects, however, such a hypothesis as nonsense because, the tiny brain of the salmon "can have no memories, no knowledge, of the road that will take him back to the very spot where he himself was spawned" (p. 28). The salmon's journey is, like the quest for self-discovery, at times ambiguous, because it is at once a movement towards individualism but also a movement towards union with others of its own kind. In the same way, as Kenn moves upstream towards self-knowledge, he also moves towards a greater knowledge of the past and present of his community through its traditions. From the day he catches the salmon, the river becomes "the river of life for Kenn" (p. 34). The movement of the salmon towards the light of the upper reaches of the river reflects the movement towards the light/delight of Kenn as child and man, schoolboy, student, soldier and scientist. The concept of delight is central to an understanding of Highland River, and, indeed, to all of Gunn's fiction from this novel onwards. For Gunn, delight is not simply the feeling of pleasure, but rather an ecstasy based, perhaps, on the realisation, of a oneness which exists between the individual and his physical, social and historical background. I would suggest that the word play between "delight" and "the light" is fundamental to an understanding of the illuminating effect of such revelation, such moments of ecstasy.

Moments of delight/illumination are accessible to Kenn both as child and as man. His attempts to think of poetry as "purely inhuman" coincide with his discovery of his own inner rhythm and the "intimations of an unhuman poetry from the sea's rhythm" (p. 77), revealing 
an aesthetic maturity which is open to experience. The young Kenn, like his predecessor, Hugh, in Morning Tide, is, however, oppressed by an education system which has little to do with real education. Although the novel is essentially a philosophical work dealing with the metaphysics of the awakening of spiritual consciousness, Gunn, as the pragmatic defender of Highland tradition, also uses the work to look critically at certain aspects of Scottish life. The irrelevance of the schooling which Kenn receives is shown through the history he is forced to learn, a history:

concerned with English kings and queens and the dates of battles. There had been the Plantagenets. Now there were Tudors. That Henry VIII had six wives did not really interest the children. They would have gaped in exactly the same way if he had had six hundred. What was important was the exact number six. A near shot, such as seven or eight, would have made the lion roar (p. 21).

Geography is equally distanced from the real world of experience of the pupils. Obliged to learn by rote the products of Leicester and Birmingham, the pupils are moved to a detachment which wore a "cunning mask" (p. 21). The school is a "narrow prison" and the outside there is:

the free rushing world of light and earth and water, of which the master knew nothing but of which Kenn knew so much that he could stand up at that moment and tell him something that would astonish him (p. 24).

The Gradgrindian "facts" which Kenn is forced to learn are ironically reflected in the life of the adult Kenn who, after his wounding in the First World War, awakens to find himself in a hospital, in Leicester which, he remembers "is famous for boots and hosiery." Kenn's real education comes as a result of his following the river, a quest towards selfdiscovery which also leads to the discovery of the history, geography, and philosophical centre of his own people, something which the Scottish education system denied him, implanting instead the dominant Anglo-centric ideology which again stresses the uncomfortable situation of Scotland within the British Empire, a fact to which Gunn constantly returns.

Kenn's individuality, his sense of himself as an individual, is inextricably linked to his consciousness of his people. Thus his discovery of the different stages of the river, as well as representing stages of his own personal development, is also related to the history of his community. As he "turned his back on this teeming harbour life and started to explore the river upwards to its source" he realised that, apart from discovering the different stages of the river he was engaged on "a thrilling exploration into the source of the river and the source of himself" (p. 52). This is linked to the history and the traditions of his people and into "the past of his forebears back beyond the dawn of history" (p. 52). All the different strands that make up the traditions and the racial mixture of his people are reflected in the river. The place names at the harbour mouth are on one side Gaelic, on the other Norse. Further upstream is an ancient Pict Broch, and further beyond are the remains of earlier, 
nameless civilisations. Such facts were not however, taught to the children of the strath. The teacher spoke of Saxons and Romans, but no mention was made of the peoples who had formed part of the traditions of the Highland people:

no Gael or Viking or Pict was ever drawn as humanly as Alfred, and Kenn in his boyhood had certainly no glimmering of an idea of how these three had filled his own glen with peaceful and violent history, with cunning tunes for the chanter, with odd, laughable twists of thought, with courage for the sea (p. 54).

The adult Kenn is aware of this "lost tradition" without having been taught it explicitly at school. The moments of realisation of the history of his people are moments of illumination associated with the river and with assimilated influences which "have given him moments of such exquisite panic, such sheer delight" (p. 54), and which have struck him far deeper than the facts learned through his formal education.

As Kenn matures, he moves first towards the Broch pool, away from the Gaelic and Norse toponyms of the mouth of the river towards the old Pictish settlements. The Broch itself is a "round circular building, at one time probably about fifty to sixty feet high" (p. 118). Inside is a beehive chamber in which Kenn almost feels the touch of "time's fingers" (p. 119). Opposite the Broch is a high knoll called Chapel Hill "though no religious ceremonies have taken part on it within living memory" (p. 119). As he follows the rise of the river he reaches the old settlements which had been crofts until the Clearances, recalling the subject matter of Butcher's Broom and the betrayal of the clan chiefs who had "risked nothing and won everything" (p. 122).

The delight which Kenn feels as he follows the course of the river is comparable to the instinctive movement of the salmon as it is drawn upstream. The text plays continually with the idea of some sort of racial memory, as if tradition itself had its own physical existence within the soul, and Kenn's "body quivered and shaped itself, as if some instinct, lost aeons ago, was still in the warm red stuff, as an echo in a rock" (p. 161)

As Kenn moves upriver, he realises that it is divided into sections, each of which is related to a stage of the development of his own consciousness. The first section of the river was the part that flowed from the sea to the Broch which "belonged to man and was populous with his affairs" (p. 198). The second part, from the Broch to the falls, out of which "boyhood rose up and faced the moors" (p. 198), and the third part was from the falls to the source, to where the river was born. The apparent paradox, exploited by Gunn, is the fact that the maturing process is a movement towards, not away from, the beginning of life. The process of spiritual growth is not a movement towards death, but rather towards birth, the awakening of the consciousness of an individual, who, despite his intrinsic loneliness, moves towards a greater understanding of his people and their traditions. The nearer Kenn gets to the source of his river, the more he is conscious of the importance of the community. His poaching of salmon, for example, is seen as a part of the legitimate right of his people to take what was their own from the rivers and forests which constituted their birthright. The flint arrow heads and stone drawings he finds give substance to his belief "in the folk, 
of whom he was one" (p. 204). Kenn realises that he is, indeed, part of a community and a tradition.

The young Kenn never reaches the source of the river, although he is aware of the very notion of the source which, he believes:

gives birth to abstract words like eternity. This is the desert place into which the prophets went to find their gods. The seers pondered here so long that they conquered their bodied and moved outside them in visions bright and clear a the evening skies beyond the moor ridge (p. 198).

As an adult Kenn once again sets out in search of the source, after having passed through a multitude of experiences. Not the least of these was his experience as a soldier in the First World War, where he is wounded. During the war he also regains contact with his brother Angus who, years before had emigrated to Canada. The spiritual death which Angus had encountered in his emigration and subsequent distancing from the river (and thus his community and its traditions) is followed by his physical death in battle. Kenn, on the other hand, although wounded, becomes a hero.

Kenn's decision to retrace the river is a natural development of the plot of the novel, whose ending, given the relationship between style and content, can only take place at the source of the river. Before embarking on this new quest, many of Kenn's ideas are expressed in conversation with his Polish colleague, Radzyn. Kenn is now working as a physicist, and Radzyn is his immediate superior. The debate between the two physicists gives the adult Kenn the opportunity to make explicit many of the themes that have earlier been implicitly suggested in the novel.

Kenn tells Radzyn that he intends to "walk a certain river to its source" (p. 210), and the Pole, sensing some spiritual purpose behind the expedition, asks Kenn if he plans to go upriver on a pilgrimage. Although Kenn denies this, he admits that he expects to have some kind of a vision. Radzyn accuses him of mysticism, reminding him that "some of your Celtic poets have lately been inclined towards the East" (p. 211). The metaphysical debate which follows outlines Kenn's belief that science is the highest art form of the twentieth century. Discovery, not creation, is the highest stage a man can aspire to, but even discovery is the acknowledgement of the already existent. "The greatest step", he claims, "any one man can take is almost negligible" (p. 213). Should a man be lucky enough to make a critical discovery, then "the thing is not his creation, it is the discovery of what is already created" (p. 213). Thus science is the dominant modern art form, because it supplies the most essential sublime for the twentieth century:

The purely objective is photographic. The purely subjective is incommunicable. How to give form to the fusion so that the most arresting communication is made? (...) If poetry is the highest expression of literature, how is it that the modern age has produced no great poetry, no poetry anyway that dominates intelligent minds, holds them with a sense of wonder of being an absolute - as it had done in the past. It must be surely because its principal attributes of wonder and curiosity and the thrill of new forms of beauty are today 
to be found in science. The way in which science has opened out the universe is the real saga or drama of our day. New words, exciting and strange, and yet more exact than words in the starkest ballad (p. 214).

The conversation moves from aesthetics to the question of "social effort." Kenn expounds his conception of a past golden age in which communal effort was the norm, and upon which the traditions of his people were based. Radzyn shows surprise at Kenn's apparent adherence to the Marxist concept of dialectical materialism, incompatible with the traditional pessimism associated, through the "Celtic Twilight" school, with the Gaels as a people. Kenn rejects the values of the "Twilight", stating that the old communal structures of Celtic society have more in common with Marxism than with the ideas of the so-called Celtic fringe:

I have never had any experience of this Twilight. In fact, if a Scot is interested in dialectical materialism or proletarian humanism, it seems to me he should study the old system in order to find out how the new system would be likely to work amongst his kind (p. 215).

For Kenn, therefore, the way forward for his people must be based on the traditions of their past. Radzyn questions the feasibility of comparing "the complex Marxian dialectic with the social simplicities" (p. 215) which were found amongst Kenn's "primitives. " Kenn answers, however, that the only simplicity was their lack of machinery but that they "were not primitive in their humanism or social recognition of one another" (p. 216).

The conversation with Radzyn is important in that it shows the intellectual maturity and decision which Kenn has reached before setting out to seek the source of his river. His decision to journey to the source is based on what was to be:

a looking back, or, at best, an effort to recapture something of the past in the present. Nothing altogether nostalgic or sentimental, because he was prepared for that, but still a certain deliberate use of the past to enrich the present (p. 224).

As he moves towards the source, he feels that time is circular, like the Pictish serpent which has its own tail in its mouth, like the circle of the sun, "held in suspension or poise and losing all dimension in an eternal now" (p. 229).

The source of the river is, of course, in itself enigmatic. Kenn finds that the river comes out of "a black hole in the earth", but that it later reappeared as the great lake, Loch Braighe na $h$ 'Aibhre. The vision that Kenn finds at the source is also ambiguous. He reaches a level of pure solitude and expects to feel a personal vision. He realises, however, that "it was writ in his nerves that could have no vision, that no figure could appear to bless him" (p. 240). It then comes to him that the vision he has been led towards is not purely an individual vision, rather it is deeper than a mere individual experience. He feels an "irrational pleasure, arising out of an absolute absence of fear", the delight which had occurred to him as a child. He sees himself walking: 
much as, in the last year or two, he had seen the little figure of the boy Kenn adventuring into the strath. What older mind, in this curious regress, was now the observer might be difficult to say, for its apprehension seemed profounder than human thought. Pict and Viking too, and Gael; the folk, through immense eras of time, sea and river, moor and loch; the abiding land: of which the departing figure was a silent emanation, more inevitable than any figure in any vision (p. 241).

Kenn then moves beyond the source of the river, to the mountains from which he can see "the grey planetary light that reveals the earth as a ball revolving slowly in the immense chasm of space" (p. 241) revealing that any attempt at ontological understanding of the river must ultimately lie beyond its purely physical environment and must inevitably encompass wider notions of the cosmos itself. In moving towards the source, Kenn has moved towards the complementary vision of self-discovery and the revelation of the past and the traditions of his community. Having discovered both himself and his role within a timeless tradition, he is faced at the end of the novel with the ultimate vision of the vast solitude of the universe.

Highland River is a work which, unfortunately, is little read outside Scotland. It is, however, perhaps the novel which best reflects the major concerns of the Scottish Renaissance writers, combining as it does the techniques of modernism with a vindication of the particularity of Scottish culture and traditions. Although the decade between the mid-1920s and mid-1930s produced a number of excellent Scottish novels by writers such as Grassic Gibbon, Naomi Mitchison, Fionn MacColla, Nan Shepherd, Willa Muir, Eric Linklater, and Gunn himself, it is arguable none have the stylistic audacity nor the metaphysical force of Highland River which, in the tradition of Hogg and Stevenson, successfully blends the local with the universal to create a work which is deserving of wider critical attention.

\section{Works Cited}

Gifford, Douglas (1991): "Neil Gunn and the Mythic Regeneration of Scotland." In D. Gunn \& I. Murray, eds., Neil Gunn's Country: Essays in Celebration of Neil Gunn. Edinburgh: Chambers.

Gunn, Neil M (1991 [1937]): Highland River. Edinburgh: Canongate.

Hart, F.R. \& J.B. Pick (1981): Neil M. Gunn: A Highland Life. Edinburgh: Polygon.

McCulloch, Margery (1987): The Novels of Neil Gunn: A Critical Study. Edinburgh: Scottish Academic Press.

Pick, J.B. (1992): The Great Shadow House: Essays on the Metaphysical Tradition in Scottish Literature. Edinburgh: Polygon.

Price, Richard (1991): Neil M. Gunn: The Fabulous Matter of Fact. Edinburgh: Edinburgh U.P. Watson, Roderick (1984): The Literature of Scotland. London: Macmillan. 